\title{
Antioxidant Effects of Selenium on Seminiferous Tubules of Immature Mice Testis
}

\author{
Davoud Kushki, Mahnaz Azarnia, and Mohammadreza Gholami ${ }^{2, *}$ \\ ${ }^{1}$ Department of Biology, Faculty of Basic Sciences, Kharazmi University, Tehran, IR Iran \\ ${ }^{2}$ Razi Herbal Medicines Research Center, Department of Anatomy, Lorestan University of Medical Sciences, Khorramabad, IR Iran \\ *Corresponding author: Mohammadreza Gholami, Razi Herbal Medicines Research Center, Department of Anatomy, Lorestan University of Medical Sciences, Khorramabad, IR Iran. \\ E-mail: gholami.mr@lums.ac.ir
}

Received 2014 July 12; Accepted 2014 August 5.

\begin{abstract}
Background:The freezing of immature testis tissue and then the transplant of it can be considered as a major step in fertility preservation for young boys with cancer, the survival of animal generation exposed to extinction and cloning animalistic desirable species. One of the most prevalent of damages in during the freezing-thawing process is oxidative stress.

Objectives: The objective of this study was to investigate the antioxidant effects of selenium compound $\left(\mathrm{Na}_{2} \mathrm{SeO}_{3}\right)$ on rate of seminiferous tubules injury in during of cryopreservation.

Materials and Methods: In this experimental study, 8 BALB/c immature male mice ( 6 - 8 days old) were randomly selected, and the testes removed surgically $(n=16)$. The testes divided into 2 groups: experimental group, control group (opposite testes). For each of the two experimental and control groups, two types of soluble (freezing solution and thawing solution) were prepared. These solutions, which contain $2 \mathrm{mg} / \mathrm{mL}$ solution of $\mathrm{Na}_{2} \mathrm{SeO}_{3}$ and control solution, were prepared in the DMEM (Dulbecco's modified eagle medium) base medium. Of each group were 4 testes into fast freezing-thawing procedure and 4 testes were into slow freezing-thawing procedure. Then this testis for analyzing injury, after preparatory process, was stained with hematoxylin-eosin.

Results: At the slow freezing-thawing procedure, seminiferous tubules injury significantly reduced in experimental group compared to control group. At the fast freezing-thawing procedure, seminiferous tubules injury significantly reduced in experimental group compared with of control group.

Conclusions: It seems that Se due to its antioxidant properties, the harmful effects of freezing-thawing process reduces and protects seminiferous tubules from oxidative injury.
\end{abstract}

Keywords: Selenium, Cryopreservation, Testis, Mice

\section{Background}

Certainly, one of the groups that require the application of new therapeutic techniques and work in the field of reproductive is children with cancer. Between $10 \%-100 \%$ of treated cancer patients depending on the type of cancer, age, type of ingredients used, the dose and duration of treatment, show a decrease in semen characteristics and an average of $15 \%-30 \%$ of them remain infertile permanently [1]. These patients due to constant exposure to radiation are vulnerable group in the reproduction. Science progress has elevated survival rate for children with cancer to $79 \%$ in recent years [2]. So the return of fertility after cancer treatment is considered as the main target [2].

Certain methods have been proposed to achieve this goal. One methods of interest to researchers in this field, to maintain natural fertility in children with cancer, is testicular tissue cryopreservation before initiation of treatment and transplantation after the end of treatment. What this process (freezing, thawing, and transplantation) is important, is that spermatogonial stem cells and testicular tissue to keep appearance, physiological and function features. Despite great advances in preparation of the technique and freezing solution, since the first testis freezing the 1960s to recent years still has not achieved the desired results. During this process, spermatogonial stem cells and testicular tissue are the susceptible most injuries to such: oxidation, apoptosis, and disintegration no return [3-9]. Among these, the most common injury is oxidative stress. During the freeze protection, reactive oxygen species (ROS) can damage the membrane and membrane processes, lysis of cells, organelles dysfunction and calcium dyshomeostasis [10]. Increased ROS and reduced GSH (glutathione) increased lipid peroxidation which leads to vacuole induce, atrophy of seminiferous tubules and apoptosis of germ cells $[11,12]$.

Theory "protect cells and tissues by adding cryoprotectant before freezing" has been researched for decades. Sufficient concentrations of cryoprotectant can protect

Copyright (C) 2015, Zahedan University of Medical Sciences. This is an open-access article distributed under the terms of the Creative Commons Attribution-NonCommercial 4.0 International License (http://creativecommons.org/licenses/by-nc/4.0/) which permits copy and redistribute the material just in noncommercial usages, provided the original work is properly cited. 
cells from oxidative stress [13]. In addition to optimizing the freezing-thawing environment by antioxidant substances seems can harmful and deadly effects of freezingthawing processes reduced to a minimum. Among the most famous antioxidant substances, selenium (Se) can be noted. Most of the texts and experience has proved the protective, anti-oxidant and anti-apoptotic effect of Se. For example, glutathione peroxides enzyme which is a powerful antioxidant, is a seleno-enzyme. Se is an element of defense in preventing injury to cells and cell membranes which is caused by hydrogen peroxide and other peroxides [14]. On the other hand, the testis is one of the target organs for Se. Selenium concentration in the testis increases during puberty and the onset of spermatogenesis. Probably due to high concentration of Se in the testis is supportive role and involvement of Se in spermatogenesis $[15,16]$.

\section{Objectives}

As regards numerous studies have confirmed the antioxidant and protective effects of Se, the purpose of this study was to investigate the antioxidant effects of Se on the rate of seminiferous tubules histological injury of BALB/C immature mice testis in during the two types of freezing-thawing process (fast freezing-thawing and slow freezing-thawing) compared with the control group.

\section{Materials and Methods}

In this experimental study, 8 immature male mice (6 8 days old) were randomly selected, and the testes were removed surgically. Sixteen testes were divided into 2 groups: experimental group, control group (opposite testes).

All experiments were performed in accordance with principles of laboratory animal care. Male 6-day old BALB/c mouse pups $(n=8)$ were obtained from Razi herbal medicines research center. Mice were euthanized by excessive doses of ketamine $\mathrm{HCl}(80 \mathrm{mg} / \mathrm{kg}$ ) and xylazine (10 mg/kg) (Pharmacia and Upiohn, Erlangen, Germany) [17] in accordance with the protocols approved by the Lorestan University Medical Sciences animal care and use committee. Every effort was made to minimize the number of animals used and reduce their suffering.

\subsection{Prepare the Freezing Solutions}

First, for each of the two experimental and control groups, 4 freezing solution were prepared in the basic culture 1, 2,3 and 4 respectively (the basic medium details are given in the Table 1) [18]. These solutions include four solutions that contain $2 \mathrm{mg} / \mathrm{mL} \mathrm{Se}\left(\mathrm{Na}_{2} \mathrm{SeO}_{3}\right)[19]$ and four control solution that contains only the basic medium that was described in the Table 1.

Fast and slow freezing procedure: For each group, after removing the testes of mice body, testicular tunica albuginea were perforated with an insulin needle then the tes- tes were transferred to its proprietary solution 1, 2, 3 and 4 respectively (any solution for 10 minutes). In order to entering testes to fast freezing-thawing procedure, four testes transferred to liquid nitrogen tank. In order to entering testes to slow freezing-thawing procedure, four testes transferred to the solution 4 and maintained at $4^{\circ} \mathrm{C}$ for one hour, at $-20^{\circ} \mathrm{C}$ for one hour, at $-70^{\circ} \mathrm{C}$ for 24 hours, respectively. Finally, were transferred to liquid nitrogen tank [20].

\subsection{Prepare the Thawing Solutions}

Before removing the testes from nitrogen tank, for each of the groups, 4 thawing solution were prepared in the basic medium 1, 2, 3 and 4 respectively (the basic medium details are given in the Table 2). These solutions include four solution $2 \mathrm{mg} / \mathrm{mL} \mathrm{Se}\left(\mathrm{Na}_{2} \mathrm{SeO}_{3}\right)$ and 4 control solution that contains only the basic medium in the Table 2.

\subsection{Fast and Slow Thawing Procedure}

After one week for fast freezing procedure testes removed from the nitrogen tank, in 30 seconds and filled with Dulbecco's modified eagle medium (DMEM) under the hood. Then rapidly transferred into the water bath $37^{\circ} \mathrm{C}$ until defreeze. Samples transferred to its proprietary solution 1, 2 and 3, respectively (any solution for 5 minutes). Then were transferred to its proprietary solution 4 and were maintained for 30 minutes in the incubator $\left(37^{\circ} \mathrm{C}\right)$. For slow freezing procedure, testes removed from the nitrogen tank and maintained at $-70^{\circ} \mathrm{C}$ for 24 hours, at $-20^{\circ} \mathrm{C}$ for one hour and at $4^{\circ} \mathrm{C}$ for one hour, respectively. Other stages were taken such as fast thawing procedure [20].

\subsection{Light Microscopy}

Samples were removed from the incubator and were fixed in Bouin's solution, dehydrated in ethanol, cleared in xylene, embedded in paraffin. Five sections $(4 \mu \mathrm{m})$ from each testis were cut at intervals of $20 \mu \mathrm{m}$ and stained with hematoxylin and eosin. Histological examinations were performed using a conventional light microscope (Diaplan, Leica Microsystem). Serial digital images were recorded at magnification of 400X. Histological characteristics of the frozen-thawed testes were compared with of control testes. Slides were coded for blinded analysis by one person and counts were performed by two other observers.

The integrity and the structural changes of controls and frozen-thawed sections were evaluated semi-quantitatively. Nuclei of intratubular cells (spermatogonia and Sertoli cells) were scored as follow:1) distinction between Sertoli cells and spermatogonia nuclei was scored as 0 if easy, 1 if difficult and 2 if impossible, 2 ) observation of nucleoli was scored as 0 if easy (visible in $40 \%$ of cells) and scored as 1 if indistinguishable (in the case of pyknotic nuclei present in a large number and very condensed),3) nuclei condensation was scored as 0 if absent or present 
Kushki D et al.

in only 1 nucleus, as 1 if $<40 \%$ of nuclei were condensed and as 2 if $>40 \%$ were pyknotic. Therefore, a total absence of nuclei alteration was scored as 0 and the worst score for nuclei morphology was 5.

The epithelium (constituted by intratubular cells) was scored as follow: 1) detachment of cells from the basement membrane was scored as 0 if absent, as 2 if partial and as 3 if total or observed on $>75 \%$ of the circumference, 2) gap formation and shrinkage were scored as 0 if absent, as 1 if slight and as 2 if more obvious. Therefore, as for nuclei, epithelium morphology was scored from 0 to 5 . The global score for each seminiferous cord section was the sum of nuclei and epithelium morphology and consequently was between $0-10$. For each testis, the global score was the mean of scores for 20 seminiferous cords sections [20].

\subsection{Statistical Analysis}

Results, seminiferous tubules analysis, of treated group with Se and control compared with Mann-Whitney U test and SPSS-22 software. Results are presented as mean \pm SD and statistical analysis were considered significant at $\mathrm{P} \leq 0.05$.

\section{Results}

Fast freezing-thawing procedure: results showed that seminiferous tubules injury significantly reduced in experimental group compared with of control (Table 3).

\subsection{Slow Freezing-Thawing Procedure}

Results showed that seminiferous tubules injury significantly reduced in experimental group compared with of control group (Table 4). As the Figure 1 suggests, in the fast freezing- thawing procedure, range of histological injury for Se group is lower than control group and its median is 5, while the control group median is 7.5. In the slow freezing-thawing procedure, range of histological injury is equal for both groups, but Se group median is 5.5 and

\begin{tabular}{|c|c|c|c|c|c|}
\hline Number of Solutions & DMEM $^{\mathbf{a}}$ & DMSO $^{\mathbf{a}}$ & Ethyleneglycol $^{\mathbf{a}}$ & $\mathrm{FBS}^{\mathbf{a}}$ & 0.5 M Sucrose \\
\hline 1 & 85 & 7.5 & 7.5 & - & + \\
\hline 2 & 70 & 15 & 15 & - & + \\
\hline 3 & 50 & 15 & 15 & 20 & + \\
\hline 4 & 50 & 15 & 15 & 20 & + \\
\hline
\end{tabular}

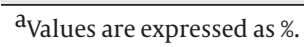

\begin{tabular}{lccc}
\hline Table 2. Details of the Thawing Solutions & & & \\
\hline Number of Solutions & DMEM $^{\mathbf{a}}$ & FBS $^{\mathbf{a}}$ & Sucrose, M \\
\hline $\mathbf{1}$ & 100 & - & 0.5 \\
$\mathbf{2}$ & 100 & - & 0.25 \\
$\mathbf{3}$ & 100 & 0.125 & - \\
$\mathbf{4}$ & 80 & 20 & - \\
\hline
\end{tabular}

${ }^{\mathrm{a}}$ Values are expressed as $\%$.

Table 3. Details of the Groups Mann-Whitney U Test

\begin{tabular}{lll}
\hline Groups & Mean \pm SD & PValue $^{\mathbf{a}}$ \\
\hline Control (f) & $7.60 \pm 0.699$ & 0.01 \\
Se $(f)$ & $5.40 \pm 0.516$ & 0.00 \\
\hline
\end{tabular}

Abbreviation: f, fast freezing-thawing procedure.

${ }^{a}$ Significant differences compared with of control group.

Table 4. Details of the Groups Mann-Whitney U Test

\begin{tabular}{lcc}
\hline Groups & Mean \pm SD & PValue $^{\mathbf{a}}$ \\
\hline $\operatorname{Control}(\mathbf{s})$ & $7.80 \pm 0.919$ & 0.01 \\
$\operatorname{Se}(\mathbf{s})$ & $5.40 \pm 0.850$ & 01 \\
\hline
\end{tabular}

Abbreviation: s, slow freezing-thawing procedure.

$\mathrm{a}_{\text {Significant differences compared with of control group. }}$ 
Kushki D et al.

control group median is 8 . Data concentration for both Se groups is $5-6$ and for both control groups is 7-8. As the Figure 2 suggest, fresh (a group of testes that in order to taking pictures, fixed immediately after remove from mice): distinction between Sertoli cells and spermatogonia and observation of nucleoli is easy, nuclei condensation, detachment of cells from the basement membrane and gap formation and shrinkage is not observed. Control group of fast freezing-thawing procedure, control group of slow freezing-thawing procedure: distinction between Sertoli cells and spermatogonia and observation of nucleoli is impossible, nuclei condensation, detachment of cells from the basement membrane and gap formation and shrinkage is observed. Selenium group of fast freezing-thawing procedure, selenium group of slow freezing-thawing procedure: distinction between Sertoli cells and spermatogonia is difficult observation of nucleoli is impossible, nuclei condensation is observed in some of nucleus but not all, detachment of cells from the basement membrane is observed, and gap formation and shrinkage are not observed.

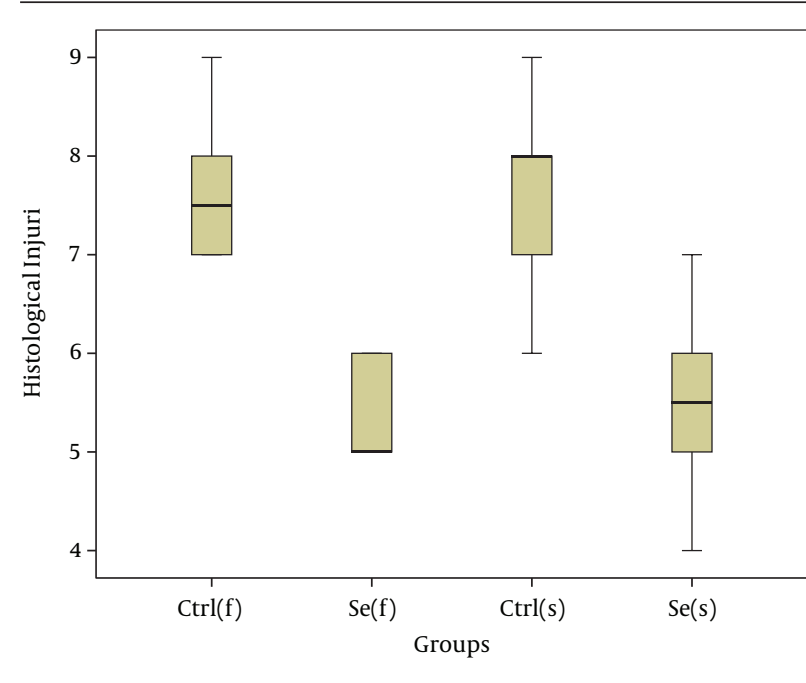

Figure 1. Analysis of Group Histological Injury After Freezing-Thawing Process

Figure 2. Seminiferous Tubules Morphology After Freezing-Thawing Process
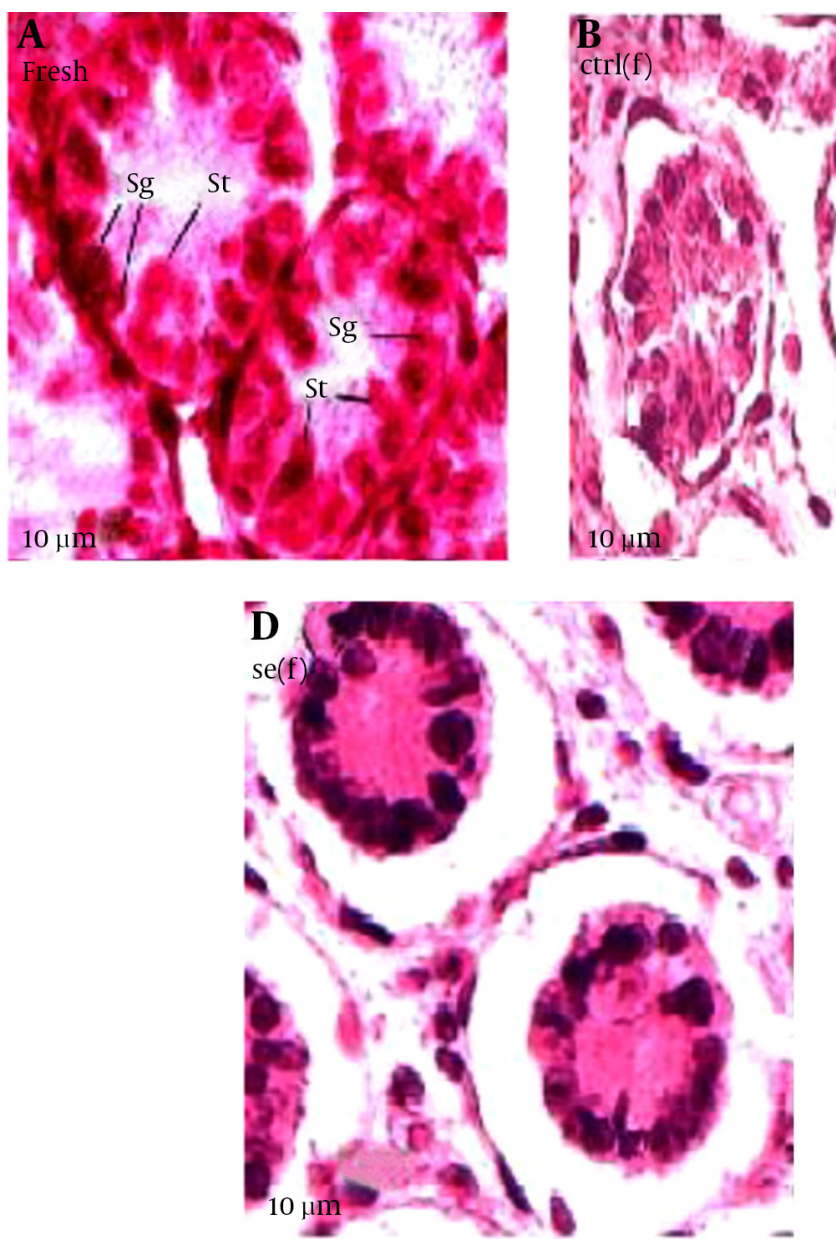
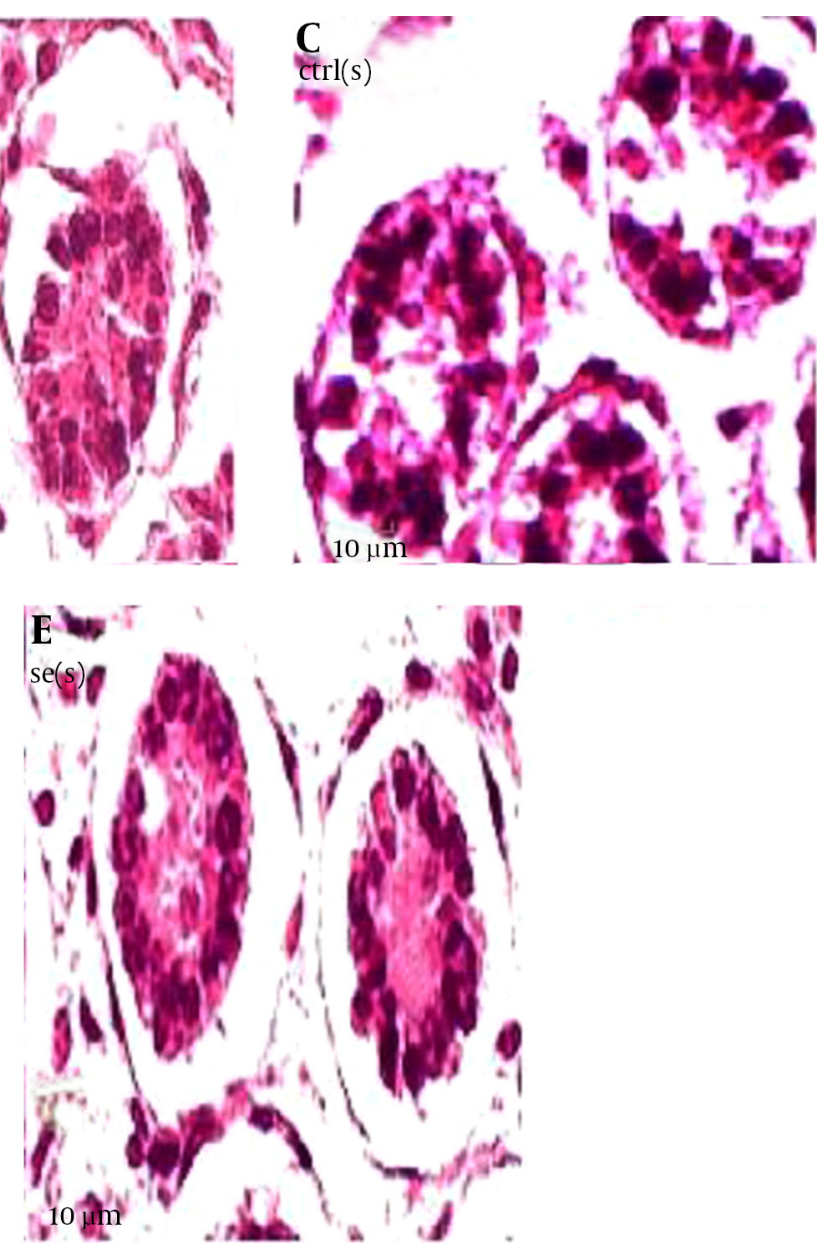
Kushki D et al.

\section{Discussion}

The results of this study showed that the existence of Se decrease the rate of seminiferous tubules histological injury of testis in during the both fast freezing-thawing and slow freezing-thawing procedure. These results are consistent with the findings of Yilmaz et al. based on decrease lipid peroxidation in testis tissue by Se [21] also is consistent with the findings of Castellini et al. based on increased levels of glutathione peroxidase in seminal plasma after supplementation with Se [22]. The result of this study which show the necessity existence of antioxidants at struggle to oxidative stress in during freezing-thawing processes, is confirm on findings of Nair et al. has compared and accessed percent of membrane oxidation and activities of antioxidant enzymes in cow's sperm and buffalo during freezing-thawing [23]. The activity of malondialdehyde enzyme, that is measure of sperm membrane oxidation, has definitely increased. But the activity of antioxidant enzymes due to the high intensity of oxidative processes in the sperm decreased. In the present study, in general, the greatest impact of antioxidants has been in the prevention of nuclei condensation and gap formation and shrinkage and the impact them on both indicator distinction between Sertoli cells and spermatogonia and observation of nucleoli was slight. Se positive effects on indicators nuclei condensation, distinction between Sertoli cells and spermatogonia and observation of nucleoli may be result of this fact that free radicals are capable, in during freezingthawing, make a great deal of injury to cell vital organs and animal body macromolecules such as proteins, lipids and carbohydrates and impact on synthesis of DNA and RNA in sperm and it is likely that conditions of oxidative stress in germ cell sexual acts in the same way and disrupt their division and differentiation $[24,25]$. But in this study, Se by its antioxidant property, as vital part of glutathione peroxidase, has been able to fight against oxidative stress acting on the nucleus and nucleolus, by mechanisms such as picking superoxide and hydrogen peroxide active species and off chain reaction. Vacuoles may be formed as a result of the loss of germ cells. Peroxidation of polyunsaturated fatty acids impairs membrane function and permeability of the membrane and cause to cell damage and death. on the other hand an important function of the glutathione peroxidase enzyme, which its antioxidant activity is relate on present of Se in the active site of enzyme, is prevent of peroxidation membrane lipid [26, 27]. So it can have be justified, Se positive effects in fight against formation of the vacuole or may this antioxidant by reduce the production of free radicals, be prevented from damage to the cell DNA and increased expression of responsible genes for its death, during freezing [28]. In the present study, minimal effect of antioxidants was on detachment of cells from the basement membrane. In connection with this effect could be many reasons and possibilities. For example this may be due to inappropriate dose of antioxidant. The optimal performance of antioxidants occurs at certain dose [29].
Dose and duration consumption of antioxidants is so important which to use the wrong dose or a short course of treatment even have the opposite effect [30]. Perhaps choosing an appropriate dose, antioxidant effect was also observed on this index. Perhaps this effect is caused by the fact that in freezing-thawing processes, in addition to oxidative stress, other powerful forces are involved in detachment of cells from the basement membrane. Consequently, the antioxidant properties of these elements alone cannot fight it.

It can be said that optimization of the freezing-thawing media of testis with $\mathrm{Se}\left(\mathrm{Na}_{2} \mathrm{SeO}_{3}\right)$ can reduces the harmful effects of fast freezing-thawing and slow freezing-thawing processes and somewhat safe seminiferous tubules tissue of the immature mice testis tissue from oxidative injury this process.

\section{Acknowledgments}

This study part of MSc thesis of Davoud Kushki that approved with number 191254400 in the Kharazmi University. The authors thank the head and staff of Razi herbal medicines research center of Lorestan University of Medical Sciences.

\section{Footnotes}

Authors' Contribution:All authors had equal role in design, work, statistical analysis and manuscript writing. Conflict of Interest:The authors declare no conflict of interest.

Funding/Support:Special thanks to Lorestan University of Medical Sciences for the financial support, Khorramabad, Iran.

\section{References}

1. Schrader M, Muller M, Straub B, Miller K. The impact of chemotherapy on male fertility: a survey of the biologic basis and clinical aspects. Reprod Toxicol. 2001;15(6):611-7. [PubMed:11738514]

2. Jenkinson HC, Hawkins MM, Stiller CA, Winter DL, Marsden HB, Stevens MC. Long-term population-based risks of second malignant neoplasms after childhood cancer in Britain. Br J Cancer. 2004;91(11):1905-10. doi:10.1038/sj.bjc.6602226. [PubMed:15534607]

3. Kanatsu-Shinohara M, Ogonuki N, Inoue K, Ogura A, Toyokuni $\mathrm{S}$, Shinohara $\mathrm{T}$. Restoration of fertility in infertile mice by transplantation of cryopreserved male germline stem cells. Hum Reprod. 2003;18(12):2660-7. [PubMed:14645188]

4. Avarbock MR, Brinster CJ, Brinster RL. Reconstitution of spermatogenesis from frozen spermatogonial stem cells. Nat Med. 1996;2(6):693-6. [PubMed: 8640563]

5. Barten EJ, Newling DW. Transplantation of the testis; from the past to the present. Int J Androl. 1996;19(4):205-11. [PubMed: 8940658]

6. Blackhall FH, Atkinson AD, Maaya MB, Ryder WD, Horne G, Brison $\mathrm{DR}$, et al. Semen cryopreservation, utilisation and reproductive outcome in men treated for Hodgkin's disease. Br J Cancer. 2002;87(4):381-4. doi:10.1038/sj.bjc.6600483. [PubMed:12177773]

7. Gittes RF, Altwein JE, Yen SS, Lee S. Testicular transplantation in the rat: long-term gonadotropin and testosterone radioimmunoassays. Surgery. 1972;72(2):187-92. [PubMed:5051539]

8. Tateno H, Kimura Y, Yanagimachi R. Sonication per se is not as deleterious to sperm chromosomes as previously inferred. Biol Reprod. 2000;63(1):341-6. [PubMed:10859277] 
9. Mazur P. Equilibrium, quasi-equilibrium, and nonequilibrium freezing of mammalian embryos. Cell Biophys. 1990;17(1):53-92. [PubMed: 1704816]

10. Fisher AB, Dodia C, Tan ZT, Ayene I, Eckenhoff RG. Oxygen-dependent lipid peroxidation during lung ischemia. J Clin Invest. 1991;88(2):674-9. doi:10.1172/JCI115352. [PubMed:1864976]

11. Huang F, Ning H, Xin QQ, Huang Y, Wang H, Zhang ZH, et al. Melatonin pretreatment attenuates 2-bromopropane-induced testicular toxicity in rats. Toxicology. 2009;256(1-2):75-82. doi:10.1016/j. tox.2008.11.005. [PubMed:19061934]

12. Son HY, Kim YB, Kang BH, Cho SW, Ha CS, Roh JK. Effects of 2-bromopropane on spermatogenesis in the Sprague-Dawley rat. Reprod Toxicol.1999;13(3):179-87. [PubMed:10378467]

13. Fuller BJ. Cryoprotectants: the essential antifreezes to protect life in the frozen state. Cryo Letters. 2004;25(6):375-88. [PubMed: 15660165]

14. Kushki D, Azarnia M, Gholami M. Antioxidant Effects of Selenium on Seminiferous Tubules of Immature Mice Testis. Zahedan J Res Med Sci. 2015:0.

15. Behne D, Weiler H, Kyriakopoulos A. Effects of selenium deficiency on testicular morphology and function in rats.J Reprod Fertil. 1996;106(2):291-7. [PubMed: 8699413]

16. Behne D, Hofer T, von Berswordt-Wallrabe R, Elger W. Selenium in the testis of the rat: studies on its regulation and its importance for the organism. J Nutr.1982;112(9):1682-7. [PubMed: 7108639]

17. Gholami M, Saki G, Hemadi M, Khodadadi A, Mohamma-di-As J. Effect of Melatonin on the Expression of Apoptotic Genes in Vitrified-thawed Spermatogonia Stem Cells Type A of 6-DayOld Mice. Iran J Basic Med Sci. 2013;16(8):906-9. [PubMed: 24106594]

18. Gholami M, Saki G, Hemadi M, Khodadadi A, Mohammadi-Asl J. Melatonin improves spermatogonial stem cells transplantation efficiency in azoospermic mice. Iran J Basic Med Sci. 2014;17(2):939. [PubMed: 24711891]

19. Shiva Shankar Reddy N, Jagan Mohanarao G, Atreja SK. Effects of adding taurine and trehalose to a tris-based egg yolk extender on buffalo (Bubalus bubalis) sperm quality following cryopreservation. Anim Reprod Sci. 2010;119(3-4):183-90. doi: 10.1016/j. anireprosci.2010.01.012. [PubMed: 20197223]

20. Milazzo JP, Vaudreuil L, Cauliez B, Gruel E, Masse L, Mousset-Sime- on $\mathrm{N}$, et al. Comparison of conditions for cryopreservation of testicular tissue from immature mice. Hum Reprod. 2008;23(1):17-28. doi:10.1093/humrep/dem355. [PubMed: 17989070]

21. Yilmaz O, Celik S, Dilsiz N. Influences of intraperitoneally and dietary administered vitamin $\mathrm{E}$ and selenium on the lipid composition in reproductive organs of male animals. Biol Chem. 1997;378(5):425-30. [PubMed: 9191029]

22. Castellini C, Lattaioli P, Bosco AD, Beghelli D. Effect of supranutritional level of dietary alpha-tocopheryl acetate and selenium on rabbit semen. Theriogenology. 2002;58(9):1723-32. [PubMed: 12472142]

23. Nair SJ, Brar AS, Ahuja CS, Sangha SP, Chaudhary KC.A comparative study on lipid peroxidation, activities of antioxidant enzymes and viability of cattle and buffalo bull spermatozoa during storage at refrigeration temperature. Anim Reprod Sci. 2006;96(1 2):21-9. doi:10.1016/j.anireprosci.2005.11.002. [PubMed:16337101]

24. Kodama H, Yamaguchi R, Fukuda J, Kasai H, Tanaka T. Increased oxidative deoxyribonucleic acid damage in the spermatozoa of infertile male patients. Fertil Steril. 1997;68(3):519-24. [PubMed: 9314926]

25. Zini A, Libman J. Sperm DNA damage: clinical significance in the era of assisted reproduction. CMAJ. 2006;175(5):495-500. doi: 10.1503/cmaj.060218. [PubMed: 16940270]

26. Sies H. Oxidative stress: oxidants and antioxidants. Exp Physiol. 1997;82(2):291-5. [PubMed: 9129943]

27. Hall L, Williams K, Perry AC, Frayne J, Jury JA. The majority of human glutathione peroxidase type 5 (GPX5) transcripts are incorrectly spliced: implications for the role of GPX5 in the male reproductive tract. Biochem J.1998;333 ( Pt 1):5-9. [PubMed: 9639555]

28. Jeong YJ, Kim MK, Song HJ, Kang EJ, Ock SA, Kumar BM, et al. Effect of alpha-tocopherol supplementation during boar semen cryopreservation on sperm characteristics and expression of apoptosis related genes. Cryobiology. 2009;58(2):181-9. doi: 10.1016/j. cryobiol.2008.12.004. [PubMed:19141297]

29. Cao G, Cutler RG. High concentrations of antioxidants may not improve defense against oxidative stress. Arch Gerontol Geriatr. 1993;17(3):189-201. [PubMed:15374318]

30. Agarwal A, Nallella KP, Allamaneni SS, Said TM. Role of antioxidants in treatment of male infertility: an overview of the literature. Reprod Biomed Online. 2004;8(6):616-27. [PubMed:15169573] 